\title{
CONVEYING THE SOCIAL STATUS MARKERS \\ OF THE LITERARY CHARACTERS OF THE TRAGEDY \\ "ROMEO AND JULIET" BY W. SHAKESPEARE \\ IN THE TRANSLATIONS OF P. KULISH
}

\section{Tarasiuk Tetiana ${ }^{1}$ \\ Kosyk Daryna²}

DOI: https://doi.org/10.30525/978-9934-571-89-3_5

In the scientific studies, the social status of the speaker is defined as "a sociolinguistic and at the same time a complex interdisciplinary concept, which reflects the legal status of a person or social group in a social system and is characterized by certain determinants, expressed in speech, lifestyles and non-verbal communication" [2, p.5]. Speech is one of the status markers. Conveying the semantic meaning of the lexemes which denote the social status of a speaker using the lexical means of the target language requires special translation strategies. It is due to the linguistic variances in the language of the original and the language of translation. For example, the English nominatives lord and sir do not have any Ukrainian equivalent, since our culture does not have a ranking system of noble titles, and therefore translators merely transcribe these names. In the situation when these lexemes lost their meaning of the title and now indicate only politeness in addressing the interlocutor, translators are forced to use their functional equivalents in the language of translation.

P. Kulish translates the addressing patterns lord and sir in the tragedy "Romeo and Juliet" by W. Shakespeare using the Ukrainian tokens, пан (pan) and добродій (dobrodij). The study has revealed a consistent distinction between title and honorable form of address to male persons. Let us consider the address My Lord, used in the communication of Capulet with young nobleman Paris. This form of courtesy, characteristic for both characters' speech (they are from titled genera), reflects symmetrical relationships and in P. Kulish's translation is rendered as мiй nане (mij pane). For instance, Count Paris: My lord, I would that Thursday were tomorrow [3, p. 114] Я-б рад, щоб той четвер сьогоднї був, Мій пане [4, p. 95]; Capuletti: Farewell, my lord [3, p. 114] Прощайте, пане мій [4, p. 95].

Sporadically, in these communicative situations translator resorts to the address добродію, namely: But now, my lord, what say you to my suit? [3, p. 21] Прошу-ж тепер, добродію, сказати, Чого менї з моӥх зальотів ждати? [4, p. 24]. This is, obviously, due to the individual-stylistic choice of the author and not the content expediency.

The Ukrainian equivalent of the lexeme sir is the lexeme добродiŭ (dobrodij), which actualizes a respectful form of address to the interlocutor.

\footnotetext{
${ }^{1}$ Lesia Ukrainka Eastern European National University, Ukraine

${ }^{2}$ Educational Complex "Vasyl Sykhomlynskyi Gymnasium No14”, Ukraine
} 
In the conversations of lovers, Juliet's address $\boldsymbol{m y}$ lord is a manifestation of respect for Romeo, for example: And follow thee, my lord, throughout the world [3, p. 57] Всюди Пійду з тобою по-сьвіту, мій пане [4, p. 54]; Art thou gone so? my love! my lord! my friend! [3, p. 116] Моя любов, мій пане, мужу, друже [4, p. 97]. Its use in the speech of many characters of the tragedy under investigation is quite frequent. For instance, the burgher's address to Tybalt, Mrs. Capuletti's nephew: $U p$, sir, go with me [3, p. 93] Вставай, добродїю!.. [4, p. 78]; Capulet and Juliet addressing young Paris: Things have fallen out, sir, so unluckily [3, p. 112] Tак речi склали ся, добродїю [4, p. 94]; That is no slander, sir, which is a truth [3, p. 130] Добродію, що правда, то не шкода [4, p. 109]; or together with the name Sir Paris [3, p. 113] Добродїю Парісе [4, p. 94]; Father Lawrence to Mr. Capulet: Sir, go you in; and, madam, go with him; And go, Sir Paris [3, p. 147] Добродїю, мадам, ідїme з нами, I ви, добродӥю Парісе, йdїmе [4, p. 122]; nurse to Mercutio: If you be he, sir, I desire some confidence with уои [3, p. 73] Коли се ви, добродїю, то менї треба щось вам сказати [4, p. 63] and many other examples.

There is a secular address of sir to Father Lawrence, albeit with the stylistically marked attribute holy, which explains the status of the interlocutor as a cleric, for example: It doth so, holy sir [3, p. 163]. However, in the Ukrainian translation добродію (dobrodiiu) the religious marking of the addressee in Balthazar's address is not reproduced: Так, так, добродӥю [4, p. 135].

Lexeme sir is sometimes revealed in the communicative situation of the married couple, namely Lady Capulet to her husband: Ay, sir; but she will none, she gives you thanks [3, p. 122] Зна, пане мій, та дякує, не хоче [4, p. 101].

The communicative model of servant-master represents the replacement of the English sir and lord by the Ukrainian token пан. For example, in the address of servants to Capulet or Romeo: I know not, sir [3, p. 40] Не знаю, пане [4, p. 39]; Things for the cook, sir; but I know not what [3, p. 141] Для кухнї, пане, та не знаю mo [4, p. 117]; I have a head, sir, that will find out logs, And never trouble Peter for the matter [3, p. 141] На дрова є і в мене, пане, товк, На що Петра про се нам турбувати? [4, p. 117]; I do beseech уоu, sir, have patience [3, p. 152] O, прошу вас, пане, Спокійте ся! [4, p. 127]; No, my good lord [3, p. 152] Нема, мій пане [4, p. 127].

At the same time, in the above-mentioned communicative situation the translator sporadically resorts to the address добродію, for example: You shall have none ill, sir [3, p. 135] Ледачих не найму, добродію [4, p. 112]; Since уои did leave it for my office, sir [3, p. 152] Бо ви, добродїю, так наказали [4, p. 126]. Such examples demonstrate the translator's desire to add expressiveness to the translation using nationally-marked units.

As for the Nurse's address to Romeo, both sir and lord are translated as добродію, which is mostly characteristic for the symmetric communication model, as in the examples: Ah sir! ah sir! - Well, death's the end of all [3, p. 108] Добродїю, смерть усьому конець [4, p. 90]; Here, sir, a ring she bid me give you, sir [3, p. 111] Ocb, добродіїю, ще перстїнь, Вона велїла вам оддати, ось! [4, p. 93]; My lord, I'll tell my lady уои will come [3, p. 111] Добродӥю, скажу Мой панянцї, щуо ви прийдете 
[4, p. 93]. In the situation of particularly trustful and cordial conversation of the Nurse with Romeo, the translator prefers a diminutive form of the Ukrainian address паночку (рапосhku), sometimes exploring it even where the original lacks it: Well, sir; my mistress is the sweetest lady [3, p. 76-77] Добре, паночку. Моя панночка наймилійма панї [4, p. 66]; Well, she shall be there [3, p. 76] Та й добре-ж, паночку; вона там буде [4, p. 65]. Note that it is not characteristic for the language of the original tragedy to express feelings through tokens with diminutive suffixes, which can not be said about the language of the investigated translation.

Both in the original and in the translation, the choice of the address depends on the communicative situation. For example, in the routine conversations, Father Lawrence addresses Paris as sir (translated as добродіŭ): On Thursday, sir? the time is very short [3, p. 128] В четвер, добродїю? Се вельми скоро [4, p. 107]; Look, sir, here comes the lady towards my cell [3, p.129] Добродїю, отсе ж idе i панна [4, p. 107]; And go, Sir Paris [3, p. 147] I ви, добродїю Парice, йdïme [4, p. 122], but when he wants to contact the interlocutor as a titular person, then he uses lord (пане): My lord, we must entreat the time alone [3, p. 131] Мій пане, мусимо на самотї [4, p. 109].

P. Kulish traditionally uses the Ukrainian lexeme панове (рапоve) to translate the address to a group of people. In the original text, it corresponds to the token gentlemen, for example: Nay, gentlemen, prepare not to be gone [3, p. 45] $O$, нï, панове, нї! ще рано, не збирайтесь [4, p. 43]; Welcome, gentlemen! [3, p. 39] Витаю вас, панове! [4, p. 37]; God ye good morrow, gentlemen [3, p. 72] Дай вам Боже добрий ранок, панове [4, p. 63]; Gentlemen, good den [3, p. 87] Добривечір, панове! [4, p. 74]. Such an address is sometimes distinguished by the etiquette attributive form of шановниї (as in the language of the original), for example: I thank yоu, honest gentlemen [3, p. 45] Чолом. Шановниї панове [4, p. 43]. In one communicative situation the English addressing gentlemen is transferred by the Ukrainian collective noun панство (panstvo): On, lusty gentlemen [3, p. 38] Ходїм, веселе панство! [4, p. 37]. An address gentleman to a single addressee is verbalized with a lexeme пане (pane) : O courteous Tybalt! honest gentleman! [3, p. 99] Тибальтоньку, ласкавий, чесний пане! [4, p. 83].

P. Kulish translates situational address Marry, bachelor [3, p. 44] by the Ukrainian lexeme паничу: Оттакої! Чи то-ж сього не знаєте, паничу? [4, p. 42]. The Ukrainian panych just nominates a young male, who is single, cf.: " 1 . The young unmarried son of a Lady and Lord" [1, p. 44].

The key findings of this study argue that in the translations of the addressing constructions determining a social status of the male addressee, P. Kulish generally used the tokens nан (pan) (the English equivalent of lord to designate the title) and добродій (dobrodij) (the English correspondent lexeme sir to express respect to the interlocutor) if the relationship is symmetrical. In the situation of a different social status of the communicators, the address of the person who takes the lower position in the social hierarchy to the higher-ranked persons is usually reproduced by a token nане (pane) used to render both English lord and sir. The translator, using lexeme добродій (dobrodij) reduces the social distance between different-status 
interlocutors, thus actualizing the characteristic feature of the Ukrainian etiquette behavior in contrast to the English-language tradition. The Ukrainian equivalent to the English addressing gentlemen is the lexeme панове (рапоve).

\section{References:}

1. Bilodid, I. K. (Ed.). (1975). Dictionary of the Ukrainian Language. (Vol. 6). Kyiv: Naukova dumka.

2. Popovych, Yu. (2017). Conveying Social Status Markers of the Literary Characters in Translation ( Case Study of the Ukrainian Translations of the $21^{\text {st }}$ cent. English Literature). Extended abstract of candidate's thesis. Kherson State University, Kherson.

3. Shakespeare, W. (2016). Romeo and Juliet. Kyiv: Znannia.

4. Shakespeare, W. (1901). Romeo and Juliet. Translated from English by P. A. Kulish. Lviv. 